\title{
RELOCATION, RELATIONSHIP AND RISK
}

\section{Martin Strous}

\section{INTRODUCTION}

When a divorced parent who has custody of a minor child wishes to move to another country or province, that parent, the non-custodian parent and the child may express disparate desires concerning relocation. The difficulty arises as to whether the rights of the child, the mobility rights of the intending mover, or the parenting rights of the opposing party should take preference. Relocation disputes are amongst "the knottiest and most disturbing problems" facing family courts (Tropea vs Tropea, 1996). There is usually little middle ground in relocation disputes (Stahl, 2006). Legal judgments, increasingly required in relocation matters, are often perceived by losing parties as "exquisitely unfair" (Carmody, 2007).

Attention to relocation disputes has increased in recent years because of conflicting legal and public opinion, high divorce rates, fathers being more involved in parenting after divorce, and population mobility (through such factors as parental conflict, remarriage, extended families, corporate downsizing, job transfers and emigration). A pertinent issue, as will be discussed in this article, is that the disruption of relationships with non-resident parents places children at risk. Readily depriving children of sufficient access to non-custodian parents to whom they are attached may violate children's rights (Strous, 2007).

\section{SOUTH AFRICAN LAW AND THE "BEST INTERESTS OF THE CHILD"}

South African courts have ruled that the principle applicable in relocation matters is the "best interests of the child" (Jackson vs Jackson, 2002; F vs F, 2005). In the case of Jackson vs Jackson (2002), the Supreme Court of Appeal stated that:

... where, following a divorce, the custodian parent wishes to emigrate, a Court will not lightly refuse leave for the children to be taken out of the country if the decision of the custodian parent is shown to be bona fide and reasonable. But this is not because of the so-called rights of the custodian parent; it is because, in most cases, even if the access by the non-custodian parent would be materially affected, it would not be in the best interests of the children that the custodian parent be thwarted in his or her endeavour to emigrate in pursuance of a decision reasonably and genuinely taken. Indeed, one can well imagine that in many situations such a refusal would inevitably result in bitterness and frustration which would adversely affect the children. But what must be stressed is that each case must be decided on its own particular facts. No two cases are precisely the same. (Cited in Maya, 2005:7)

In $F$ vs $F$ (2005) the Supreme Court of Appeal stipulated that, in deciding whether or not relocation will be in the child's best interests, the court must carefully evaluate, weigh and balance a myriad of competing factors, including the child's wishes in appropriate cases. The reasonableness of the custodian's decision to relocate, the practical and other considerations on which such decision is based, and the extent to which the custodian has engaged with and properly thought through the real advantages and disadvantages to the child of the proposed move are all aspects that must be carefully scrutinised in determining the best interests of the child.

The Supreme Court of Appeal in F vs F (2005) upheld an earlier court decision (Ford vs Ford, 2003) that stated inter alia that there was an obligation on the appellant to place the 
consequence of interrupting a close psychological and emotional bond which a child has with the non-custodial parent at the forefront of a decision to relocate. However, in $B$ vs $M$ (2006) the Witwatersrand Local Division made the unusual move of disagreeing with a higher court and stated that "to hold that the relocating parent must place this close psychological and emotional bond which the child may have with the non-relocating parent at the "forefront" of any decision regarding the future of the child ignores the multiplicity of factors which such parent must take into account and the context within which each such audit must be performed."

No matter the weight that judges have accorded various aspects of a best interests analysis, the courts' consistent adherence to the best interests standard is in keeping with the common law and legislation, including the Constitution. Section 28 (2) of the Constitution of the Republic of South Africa (Act 108 of 1996) enshrines the "best interests of the child" principle. The principle is also articulated in Section 9 of the Children's Act of 2005, which instructs that "in all matters concerning the care, protection and well-being of a child, the standard that the child's best interest is of paramount importance must be applied".

Section 7(1) of the Children's Act stipulates that in determining the best interests of the child standard, the following factors must be taken into consideration, where relevant:

- the nature of the personal relationship between

- the child and the parents, or any specific parent; and

- the child and any other care-giver or person relevant in those circumstances;

- the attitude of the parents, or any specific parent, towards

- the child; and

- the exercise of parental responsibilities and rights in respect of the child; and

- the capacity of the parents, or any specific parent, or of any other care-giver or person, to provide for the needs of the child, including emotional and intellectual needs;

- the likely effect on the child of any change in the child's circumstances, including the likely effect on the child of any separation from

- both or either of the parents; or

- any brother or sister or other child, or any other care-giver or person, with whom the child has been living;

- the practical difficulty and expense of a child having contact with the parents, or any specific parent, and whether that difficulty or expense will substantially affect the child's right to maintain personal relations and direct contact with the parents, or any specific parent, on a regular basis;

- the need for the child

- to remain in the care of his or her parent, family and extended family; and

- to maintain a connection with his or her family, extended family, culture or tradition;

- the child's

- age, maturity and stage of development;

- gender; 
- background; and

- any other relevant characteristics of the child;

- the child's physical and emotional security and his or her intellectual, emotional, social and cultural development;

- any disability that a child may have;

- any chronic illness from which a child may suffer;

- any other relevant characteristics of the child;

- the need for a child to be brought up within a stable family environment and, where this is not possible, in an environment resembling as closely as possible a caring family environment;

- the need to protect the child from any physical or psychological harm that may be caused by - subjecting the child to maltreatment, abuse, neglect, exploitation or degradation or exposing the child to violence or exploitation or other harmful behaviour; or

- exposing the child to maltreatment, abuse, degradation, ill-treatment;

- any family violence involving the child or a family member of the child; and

- which action or decision would avoid or minimise further legal or administrative proceedings in relation to the child.

\section{RELOCATION AND RISK}

Within the framework of the "best interests of the child", it is important for forensic experts to be knowledgeable of the risk of harm associated with relocation as well as protective factors that might reduce that risk (Austin, 2008). Austin (2008) states that relocation for children of divorce stands as a general risk factor for long-term behavioural outcomes. He reviews literature that residential mobility is correlated with poor academic performance, school dropout rate, drug and alcohol abuse, pre-marital child bearing, and a variety of behavioural problems. Psychologists and social workers who specialise in issues of custody and access are frequently asked to provide expert forensic testimony in court and they should have knowledge of such risks.

Research on the effects of relocation is not determinative for each specific case (Austin \& Gould, 2006). Psychological research needs to be considered within the unique context of each case and specific family dynamics across a number of variables (Stahl, 2006; Austin, 2008). As in custody and access cases, evaluators should integrate research with the meaning of direct observations, interview information, and collateral information concerning children, parents and family processes (Gould \& Stahl, 2001).

\section{THE RISK OF DISRUPTED RELATIONSHIPS}

There is substantial research documenting the adverse effects of disrupted parent-child relationships on children's development, adjustment and educational attainment (Bowlby, 1952; Kohut, 1977; Sroufe \& Waters, 1977; Masterson, 1990; Steele, 2002; Kelly \& Lamb, 2003). Included in this research are findings that, regardless of conflict between parents, children of divorced parents who are separated from one parent due to the other parent's relocating are significantly less well off on many child mental and physical health measures compared to those children whose parents do not move away (Braver, Ellman \& Fabricius, 2003; Fabricius \& Braver, 2006). 
Austin and Gould (2006) contend that when circumstances require a child to relocate with a parent, and there have been two highly involved parents, then the revised parenting plan always needs to be based on a goal of harm mitigation. This implies that a degree of harm is almost inevitable and should be anticipated.

Separations from a primary attachment figure in a child's early years are regarded as stressful and perilous (Bowlby, 1973). A fundamental premise of attachment theory (Bowlby, 1952; Sroufe \& Waters, 1977) is that consistent parental availability and responsiveness facilitate a child's secure emotional connection to the parent, and the child's subsequent development of healthy independence. Securely attached children tend to be more independent, socially competent, inquisitive, cooperative and empathic than insecurely attached children (Kelly \& Lamb, 2000). They tend to enjoy higher self-esteem and demonstrate more persistence and flexibility on problem-solving tasks than children who experience insecurity in the parental relationship, perceptions of rejection by the parent, and anger toward the parent (Bowlby, 1952; Ainsworth, 1973, 1989; Sroufe \& Waters, 1977; Kelly \& Lamb, 2000).

Braver et al. (2003) found significant negative effects associated with long-distance parental moves. As compared with divorced families in which neither parent moved, students from families in which one parent moved received less financial support from their parents, worried more about that support, felt more hostility in their interpersonal relations, suffered more distress related to their parents' divorce, perceived their parents less favourably as sources of emotional support and as role models, believed the quality of their parents' relations with each other to be worse, and rated themselves less favourably on their general physical health, their general life satisfaction, and their personal and emotional adjustment, according to the study. This research is compatible with attachment theory and research on the importance of not diluting primary attachments. While explanations for the Braver, Ellman and Fabricius research results could include that moving per se tends to be harmful for children, that families with characteristics that are harmful for children also tend to move, or a combination of both or other factors, the researchers conclude that there is no empirical basis on which to justify a presumption that a move by a custodial parent to a destination she or he plausibly believes will improve their life will necessarily confer benefits on the children they take with them.

Some mental health and legal professionals (e.g. Wallerstein \& Tanke, 1996) continue to maintain that the relationship between a child and the residential/relocating parent offers sufficient protection against the risks of relocating. Austin and Gould (2006) point out that the opinion of this group is largely based on older data sets describing more sex-role-specific parenting roles, when fathers played a secondary parenting role. Moreover, the studies cited by this group almost always use the potentially biased, self-report of mothers addressing both their level of parental involvement and the level of parental involvement of fathers.

Wallerstein, emphasising the importance of the primary attachment figure, wrote a brief (1995, published as Wallerstein \& Tanke, 1996) that was influential in California and a number of other USA state courts' decisions to permit relocation moves (e.g. Burgess vs. Burgess, 1996). Her standpoint has been severely criticised (e.g. Gardner, 1998a, 1998b; Kelly \& Lamb, 2000; Fabricius, 2003; Warshak, 2003). Warshak (2000) concluded that a comprehensive and critical reading of more than 75 studies generally supports a policy of encouraging both parents to remain in close proximity to their children. Warshak wrote a brief in another California Supreme Court case (LaMusga) that reinterpreted Burgess in keeping with a wider body of more recent research than that undertaken by Wallerstein. Wallerstein also submitted a brief in the LaMusga case, but the court's near unanimous decision paralleled the arguments made in 
the Warshak brief, which was signed by 28 eminent authorities in the field of divorce ${ }^{1}$ (R.A. Warshak, personal communication, 11 July 2007).

Austin and Gould (2006) point out that researchers such as Warshak base their advocacy on more current research and quality longitudinal studies than researchers such as Wallerstein had done. For instance, Hetherington's 40-year representative sample study of families (Hetherington \& Kelly, 2002) and Amato's large sample representative survey studies (Amato \& Sobolewski, 2001) support the generalisation that children's overall, long-term adjustment to divorce is greater when there is the opportunity for meaningful relationships with both parents.

Austin (2008) notes that while the quality of the relationship between a child and the residential/relocating parent serves as a protective factor against the risk of relocation, this protective factor does not insulate the child so effectively that the level of risk is minimal. Even if children of divorce who are securely attached to one parent may show satisfactory adjustment, they will do even better with secure relationships with two involved parents under conditions of low exposure to conflict (Amato \& Sobolewski, 2001; Kelly \& Emery, 2003; cited by Austin, 2008).

In stressing the importance of the primary attachment figure, the viability of shared parenting has often been underestimated. Attachment theory acknowledges that children can form more than one attachment, to fathers as well as to mothers. Even though a custodial parent may be the primary attachment figure, bonding with a non-custodial parent is common and often deep (Gardner, 1998a). Children are capable of, and often profit from, multiple simultaneous attachments (Ainsworth, 1989; Lamb, 1997). According to a brief written by Warshak (2004) and endorsed by other eminent authorities, studies of children's attitudes about their parents' divorce consistently reveal that most children long for more time with each parent and wish their parents would reunite; and children and young adults described the loss of contact with a parent as the chief negative aspect of divorce.

Relocation moves are often stressful, for any person. If the primary caregivers and significant others in a child's life remain constant, the child may not be as influenced by adverse transitional problems often associated with geographic relocation. If the child is removed from principal caregivers and important others, multiple losses and enormous risk could be encountered. With remarkable uniformity, young college adults who have lived through their parents' divorces believe that equal time spent living with each parent after divorce is best for children (Fabricius, 2003).

\section{APPLICABILITY OF RESEARCH TO SOUTH AFRICA}

In South Africa the Children's Act of 2005 (chapter 3, part 2), which came into effect in July 2007 , is compatible in a number of ways with an ethos of continuing shared parental responsibility. It provides explicit recognition for the co-exercise of parental responsibilities and rights, where such responsibilities and rights have not otherwise been curtailed by order of a court. Moreover, section 35 of the Act stipulates penalties for preventing the exercise of parental responsibilities and rights.

\footnotetext{
${ }^{1}$ D. Eisenberg for C. Ahrons, W. Austin, S. Braver, J. Bray, D. Demo, R. Emery, W. Fabricius, M. Gottlieb, J Guidubaldi, J. Kelly, M. Kline Pruett, M. Lamb, J. Lebow, P. McKenry, K. Pasley, I. Ricci, J. Santrock, R.Warshak, S. Brown, J. Flens, M. Fraga, L. Greenberg, N. Grossman, L. Hunter, E. Baranoff McKenzie, N. Williams Olesen, G. Rick and J. Tyler.
} 
It remains to be seen how the courts will interpret the Children's Act in the case of relocation matters. Moves towards an ethos of continuing shared parental responsibility often result in the safeguarding of a child's rights to the psychological benefits that accrue from secure relationships with both parents. In England and Wales, where the test for relocation cases previously favoured the custodial parent, there has been a reported shift to a continuing shared parental responsibility model and court decisions have shown a greater willingness on the part of judges to prohibit moves that would interfere with ongoing, positive access for the noncustodian (Bailey \& Giroux, 1998; Worwood \& Massey, 2004). In Australia, which has also moved to a continuing shared parental responsibility model similar to that of England and Wales, the Court rejected the adoption of a presumption in favour of relocation (Bailey \& Giroux, 1998). In the South African case of Ford vs Ford (2003) Judge Weiner stated that, in her view, in deciding on relocation applications, a major consideration should be the detrimental consequences of interrupting a close psychological and emotional bond that a child has with the non-custodial parent. A custodian parent will not be able to force a decision - even if reasonable and balanced in some respects - to relocate, and in so doing pay scant regard to the fact that the access that children have to their remaining parent will be seriously curtailed (Ford vs Ford, 2003).

Despite the increasing confluence of legal decisions on relocation matters and literature on continuing shared parental, an appeal court judge in the Witwatersrand Local Division has on a number of occasions challenged the applicability of expert psychological opinion and research on relocation matters. Justice Satchwell has been perceived by some as distorting or negating psychological evidence and running the risk of placing women's rights above children's rights (F vs F, 2006; McGregor, 2006; Strous, 2007). She has further queried the applicability of relocation research to South Africa. In $B$ vs $M$ (2006, paragraph 53) Justice Satchwell commented, "We ... cannot ourselves make the leap from experiences in the United States or Canada to the South African situation since we have no knowledge of the extent to which the research is locality specific or culture based. Its relevance to the South African experience in general or to this litigation in particular has not been outlined to us".

It is important for mental health practitioners to be sensitive to issues of culture, gender, race and social context. However, we need to be careful of extreme positions of contextual relativism. Discounting well-researched knowledge on the basis of supposed, potential contextual differences may cause one to "lose the big picture" (Swartz, 1998:18). Overemphasis on cultural or geographic specifics could disregard human universals and render both mental health professionals and judges incapable of making any decisions. A useful multicultural perspective explains behaviour both in terms of culturally learnt perspectives that are unique to a particular culture and common ground universals that are shared across cultures (Pedersen, 1991).

South African society is multicultural and in flux. For instance, in the 1980s, the main form of childcare amongst Black working-class women was the extended family (Cock, Emdon \& Klugman, 1986). Most White families employed domestic workers, often as child-minders (Hickson \& Strous, 1993).

Under apartheid, iniquitous social engineering resulted in massive migrant labour, the splitting of Black families, poverty and oppression. Both African customary law considerations and the results of apartheid legislation led to many demands for father custody (Burman \& Fuchs, 1986). One study (Mboya \& Nesengani, 1999), suggested that a father's absence as a result of 
the system of migrant labour had deleterious effects on the scholastic performance of young people.

In the after word to a book on how different groups experience childhood in a divided society, Pamela Reynolds (1986:396) wrote:

There is one right that should be enshrined in the nation's constitution and assured by law and its strict implementation, and that is the right of a child to live with his or her mother and father. How extraordinary that there is a country that legislates against this fundamental right: a country that enforces through vast, complex machinery at enormous cost the separation of child and parent. Given the high rate of divorce in South Africa and the destruction of family life, many children cannot live with both parents, but legislation such as that which controls movement of people and access to housing in jobs should not determine with whom the child may or may not live nor where.

With the demise of apartheid South African mental health practitioners need to be sensitive to processes of acculturation for people who stand at the centre of the country's transitional process (Nortier \& Theron, 1998). In the area of child psychology and custody evaluation, many South African practitioners find relevance in the notion of attachment. According to the chief psychologist at the Child and Family Unit, Johannesburg Hospital, which is a large psychiatric and psychology training rotation catering to a broad and diverse population, unless there is compelling reason to contradict it, maintaining and fostering positive relationships between children and both their parents remains a priority in terms of child mental health (C. Smith, personal communication, 20 September 2007). One of the greatest contributions to date of cross-cultural studies on attachment is the understanding that in both Western and nonWestern cultures children have relationships with several attachment figures rather than just one. Research from around the world supports the claim that all infants develop attachment relationships, secure or insecure, with their primary caregivers, and that secure attachments are highly prized.

\section{CONCLUSION}

Relocation disputes necessitate painful decisions and painful trade-offs. Relocation may be beneficial where children are exposed to such factors as less crime, less abuse, easier access to extended family, better schools, safer communities, emotional and financial improvement, and/or separation from an abusive or disturbed parent. Moreover, non-removal orders can hinder a non-custodian parent in his or her preferences, resulting in that parent becoming frustrated and bitter. However, the potential benefits of relocation need to be weighed up against any adverse consequences of removing a child from his or her environment. Before removing a child from the sphere of influence of the non-residential parent, a prime consideration should be the significant risk that is associated with an attenuated parent-child relationship. Psychological research needs to be considered within the unique context of each case and specific family dynamics across a number of variables (Stahl, 2006; Strous 2007; Austin, 2008).

\section{REFERENCES}

AINSWORTH, M.D.S. 1973. The development of infant-mother attachment. In: CALDWELL, B.M.C. \& RICKIUTI, H.N. (eds) Review of child development research. Child development and social policy (vol 3). Chicago and London: University Of Chicago Press: 1-94. 
AINSWORTH, M.D.S. 1989. Attachments beyond infancy. American Psychologist, 44:709716.

AMATO, P.R. \& SOBOLEWSKI, J.M. 2001. The effects of divorce and marital discord on adult children's psychological well being. American Sociological Review, 66:900-921.

AUSTIN, W. 2008. Relocation, research, and forensic evaluation. Family Court Review, 46(1):136-149.

AUSTIN, G. \& GOULD, W. 2006. Exploring three functions in child custody evaluation for the relocation case: prediction, investigation, and making recommendations for a long-distance parenting plan. Journal of Child Custody, 3(3/4):63-108.

BAILEY, M. \& GIROUX, M. 1998. Relocation of custodial parents: final report. Available: http://www.swc-cfc.gc.ca/. [Retrieved: 21/05/2006 from the Status of Women Canada site].

BOWLBY, J. 1952. Maternal care and mental health (2nd ed). Geneva: World Health Organisation.

BOWLBY, J. 1973. Attachment and loss, Volume 2: separation, anxiety and anger. New York: Basic Books.

BRAVER, S.L., ELLMAN, I.M. \& FABRICIUS, W.V. 2003. Relocation of children after divorce and children's best interests: new evidence and legal considerations. Journal of Family Psychology, 17:206-219.

BURMAN, S. \& FUCHS, R. 1986. When families split: custody on divorce in South Africa. In: BURMAN, S. \& REYNOLDS, P. (eds) Growing up in a divided society. Johannesburg: Ravan Press: 115-138.

BURGESS V. BURGESS, 1996. 13 Cal 4th 25.

B VS M, 2006 (9) BCLR 1034 (W). Available: www.cfcr.org.za/wp-content/uploads/ 2007/02/B\%20v\%20M.pdf. [Retrieved: 16/08/2007].

CARMODY, T. 2007. Child relocation: an intractable international family law problem. Family Court Review, 45(2):214-246.

COCK, J., EMDON, E. \& KLUGMAN, B. 1986. The care of the apartheid child: an urban African study. In: BURMAN, S. \& REYNOLDS, P. (eds) Growing up in a divided society. Johannesburg: Ravan Press: 66-92.

FABRICIUS, W.V. 2003. Listening to children of divorce: new findings that diverge from Wallerstein, Lewis, and Blakeslee. Family Relations, 52(4):385-396.

FABRICIUS, V. \& BRAVER, L. 2006. Relocation, parent conflict, and domestic violence: independent risk factors for children of divorce. Journal of Child Custody, 3(3/4):7-27.

FORD VS FORD. 2003. Judgement in the matter between Margaret Helen Ford, Applicant, and Michael George William Ford, Respondent. In the High Court of South Africa (Witwatersrand Local Division). Case No: 5240/03. Available: http://www.legalbrief.co.za/filemgmt/ visit.php?lid=109. [Retrieved: 21/05/2007].

FORD VS FORD. 2006. (3) SA 42 (SCA). Available: Error! Hyperlink reference not valid.. za/sca_judg/sca_2005/52_05.pdf. [Retrieved 08/02/2007].

GARDNER, R.A. 1998a. The Burgess decision and the Wallerstein brief. American Academy of Psychiatry and the Law, 26:425-431. 
GARDNER, R.A. 1998b. The parental alienation syndrome $\left(2^{\text {nd }}\right.$ ed $)$. Cresskill, N.J.: Creative Therapeutics.

GOULD, J.W. \& STAHL, P.M. 2001. Never paint by the numbers: a response to Kelly and Lamb (2000), Solomon and Biringen (2001), and Lamb and Kelly (2001). Family Court Review, 39(4):372-376.

HETHERINGTON, E.M. \& KELLY, J. 2002. Divorce reconsidered: for better or for worse. New York: Norton.

HICKSON, J. \& STROUS, M. 1993. The plight of South African women domestics: providing the ultra-exploited with psychologically empowering mental health services. Journal of Black Studies, 24(1):109-122.

JACKSON VS JACKSON 2002. (2) SA 303 (SCA).

KELLY, J.B. \& EMERY, R.E. 2003. Children's adjustment following divorce: risk and resilience perspectives. Family Relations, 52:352-362.

KELLY, J.B. \& LAMB, M.E. 2000. Using child development research to make appropriate custody and access decisions. Family and Conciliation Courts Review, 38:297-311.

KELLY, J.B. \& LAMB, M.E. 2003. Developmental issues in relocation cases involving young children: when, whether and how? Journal of Family Psychology, 17(2):193-205.

KOHUT, H. 1977. The restoration of the self. New York: International Universities Press.

LAMB, M. E. 1997. The development of infant--father attachments. In: LAMB, M.E. (ed), The role of the father in child development $\left(3^{\text {rd }}\right.$ ed). New York: Wiley: 104-120, 332-342.

MASTERSON, J.F. 1990. Psychotherapy of borderline and narcissistic disorders: establishing a therapeutic alliance. Journal of Personality Disorders, 4:182-191.

MAYA, M.M.L. 2005. Judgement in the matter between Helen Margaret Ford, Appellant, and Michael George William Ford, Respondent. In The Supreme Court of Appeal of South Africa. Case No: 52/05.

MBOYA, M.M. \& NESENGANI, R.I. 1999. Migrant labour in South Africa: a comparative analysis of the academic achievement of father-present and father-absent adolescents. Adolescence. Available: http://findarticles.com/p/articles/mi_m2248/is 136 34/ai 59810234. [Retrieved: 26/08/2007].

McGREGOR, E. 2006. January 10. Divorce, distance and the best interest of the child. Business Day. Available: http://www.businessday.co.za :80/Articles/Tarkarticle.aspx?ID $=1832223$. [Retrieved: 24/08/2007].

MZOBANZI, M. \& NESENGANI, R.I. 1999. Migrant labor in South Africa: a comparative analysis of the academic achievement of father-present and father-absent adolescents. Adolescence (winter) Available: http://findarticles.com/p/ articles/mi_m2248/is 136 34/ai 59810234. [Retrieved: 21/08/2007].

NORTIER, S.E. \& THERON, W.H. 1998. Acculturation in post-apartheid South Africa: a time of healing or a time of identity confusion and loss? In: SCHLEBUSCH, L. (ed), South Africa beyond transition: psychological well-being. Proceedings of the 3rd Annual Congress of the Psychological Society of South Africa. Psyssa: 230-233. 
PEDERSEN, P.B. 1991. Multiculturalism as a generic approach to counselling. Journal of Counselling and Development, 70:6-12.

REYNOLDS, P. 1986. Afterword. In: BURMAN, S. \& REYNOLDS, P. (eds) Growing up in a divided society. Johannesburg, Ravan Press: 393-398.

SROUFE, L.A., \& WATERS, E. 1977. Attachment as an organizational construct. Child Development, 48(4):1184-1199.

STAHL, P. 2006. Introduction to the volume on relocation issues in child custody cases. Journal of Child Custody, 3(3/4):1-5.

STEELE, H. 2002. State of the art: attachment theory. The Psychologist, 15(10):518-523.

STROUS, M. 2007. Post-divorce relocation: in the best interests of the child? South African Journal of Psychology, 37(2):223-243.

SWARTZ, L. 1998. Culture and mental health: a Southern African view. Cape Town: Oxford University Press.

THE CONSTITUTION OF THE REPUBLIC OF SOUTH AFRICA ACT 108 OF 1996. THE CHILDREN'S ACT, 38 of 2005.

TROPEA VS TROPEA. 1996. 665 N.E. 2d 145, 148 (N.Y. 1996).

WALLERSTEIN, J.S. 1995, December 7. Amica Curiae brief of Dr Judith S. Wallerstein, filed in Cause No. S 046116, in Re the marriage of Burgess, Supreme Court of the State of California.

WALLERSTEIN, J.S. \& TANKE, T.J. 1996. To move or not to move: psychological and legal considerations in the relocation of children following divorce. Family Law Quarterly, 30:305310.

WARSHAK, R.A. 2000. Social science and children's best interests in relocation cases: Burgess revisited. Family Law Quarterly, 34:83-113.

WARSHAK, R.A. 2003. Payoffs and pitfalls of listening to children. Family Relations, 54(4):373-384.

WARSHAK, R.A. 2004. Brief of Amici Curiae on behalf of minor children. Re: In re the Marriage of Susan Poston Navarro (LaMusga) and Gary LaMusga.

WORWOOD, A. \& MASSEY, W. 2004. International relocation of children from England. IAML Newsletter, 15:6-10.

Dr Martin Strous is an educational psychologist in private practice in Johannesburg, South Africa. 